\title{
STUDI KERAGAMAN MESOFAUNA TANAH PADA BEBERAPA VEGETASI DI KAWASAN TAMAN NASIONAL KELIMUTU
}

\author{
Fendra Suarmadi ${ }^{1}$, Sri Wahyuni ${ }^{2}$, WillybrordusLanamana ${ }^{3}$ \\ Program Studi Agroteknologi, Fakultas Pertanian Universitas Flores \\ Fend_ra84@yahoo.co.id
}

\begin{abstract}
The goal of this research was to understand the diversity of soil mesofauna native to different plant habitats in the area of Kelimutu National Park and to understand how the dominant soil mesofaunal populations vary depending on vegetative diversity. This research was conducted in a number of different vegetation habitat zones according to the intensity of land use in the area of Kelimutu National Park and in the laboratories at the University of Flores in the city of Ende. This research was designed in a linear method and sampled vegetation from areas labelled VR (Vacciniumvaringiaefoliumdan Rhododendron renschiamum), $\mathrm{VCa}$ (mixed forest) and $\mathrm{VC}$ (coniferous forest).

The results of this research show that the area near Kelimutu National Park contain low to medium diversity. Low diversity was observed in areas with vegetation VR with5 types of soil mesofauna $\left(\mathrm{H}^{\prime}: 1.153\right)$ whereas medium diversity was observed in areas with vegetation $\mathrm{VCa}$, with researchers finding 7 types of soil mesofauna $\left(\mathrm{H}^{\prime}: 1.771\right)$. Six types of soil mesofauna were found in areas with vegetation type $\mathrm{VC}\left(\mathrm{H}^{\prime}: 1.727\right)$.

Vegetative diversity was found to be linked to the increasing dominance ofsoil mesofauna in the area of Kelimutu National Park. The highest value of vegetative diversity was $\left(\mathrm{H}^{\prime}: 1.821\right)$, found in area $\mathrm{VCa}$ with dominance of soil mesofauna $(\mathrm{E}: 0,85)$. For area VR, the vegetatitve diversity was $\left(\mathrm{H}^{\prime}: 1,771\right)$ with a dominant soil mesofauna value of $(E: 0.72)$ and for vegetation $\mathrm{VC}$ the vegetative diversity was $\left(\mathrm{H}^{\prime}: 0.861\right)$ with dominant soil mesofauna value of (E: 0,28).
\end{abstract}

Key Words: Mesofauna, hatbitat, vegetation, Kelimutu National Park

\section{PENDAHULUAN}

Taman Nasional Kelimutu merupakan kawasan pelestarian alam yang mengemban 3 (tiga) misi penting dan harus dilaksanakan yaitu perlindungan kawasan sebagai sistem penyangga kehidupan, pengawetan keanekaragaman hayati beserta ekosistemnya dan pemanfaatan secara lestari (Anonymous, 2006).

Kawasan Taman Nasional Kelimutu beriklim tropis dengan curah hujan ratarata berkisar antara $1.615-3.363$ $\mathrm{mm} /$ tahun. Suhu udara berkisar antara $25,5^{\circ} \mathrm{C}-31^{\circ} \mathrm{C}$, suhu minimum berkisar $11,6^{\circ} \mathrm{C}$ terjadi pada bulan Juli - Agustus. Jenis tanah dalam kawasan terdiri dari Regosol, Mediteran dan Latosol (Anonymous, 2006). Tanah Regosol paling dominan persebarannya dalam kawasan Taman Nasional Kelimutu dengan vegetasi yang tumbuh diantaranya Casuarina junghuniana (Bu), Eucalyptus urophilla (Ampupu) dan jenis vegetasi hutan rimba campuran serta beberapa lokasi terdapat tanah pasir yang merupakan endapan vulkanik dengan vegetasi yang didominasi oleh vegetasi Vaccinium varingiaefolium (Urangoni) 
dan Rhododendron renschianum (Turuwara). (Ekawasta, 1991).

Taman Nasional Kelimutu memiliki ketinggian tempat $1400-1731$ m dpl, berdasarkan ketinggian tempat dan suhu udara dapat dibagi menjadi 2 tipe ekosistem hutan yaitu submontane dan montane (Anonymous, 2006). Ekosistem hutan submontane berada pada ketinggian antara $1.000-1.500 \mathrm{~m}$ dpl, dengan kisaran suhu $27^{\circ} \mathrm{C}-30^{\circ} \mathrm{C}$. Formasi hutan submontane didominasi oleh hutan alam dengan jenis vegetasi hutan lebih banyak dari suku Euphorbiaceae dan Moraceae. Taman Nasional Kelimutu sebagaian besar tergolong dalam ekosistem tipe submontane. Ekosistem montane terletak di puncak-puncak gunung dengan ketinggian antara 1.500 $1.700 \mathrm{~m}$ dpl dengan kisaran suhu $25^{\circ} \mathrm{C}-$ $27^{\circ} \mathrm{C}$. Tipe vegetasi pada ekosistem montane ini didominasi jenis Casuarina junghuniana $\quad(\mathrm{Bu}), \quad$ Glochidion philippicum (Longgo Baja), Eurya acuminata (toko kata), dan Homalantus giganteus (Kebu). Pada bagian bawah terdapat Eupatorium odoratum (Kerinyu), Imperata cylindrica (Ki), Pteris sp (Paku) dan Gleichenia linearis (Kepa) (Anonymous, 2007)

Berdasarkan jenis vegetasi pembentuk hutan Kawasan Taman Nasional Kelimutu dapat diklasifikasi menjadi 2 (dua) tipe yaitu hutan homogen dan hutan rimba campuran. Hutan homogen berupa vegetasi Casuarina junghuniana $(\mathrm{Bu})$ tersebar di sekitar puncak gunung kelimutu pada punggung bukit dan vegetasi Eucalyptus urophilla (Атрири) merupakan hasil reboisasi tersebar di seluruh zone reboisasi, sedangkan hutan rimba campuran relatif luas tersebar di seluruh kawasan Taman Nasional Kelimutu dan cenderung menutupi lembah-lembah perbukitan (Anonymous, 2006).

Keanekaragaman vegetasi dalam suatu ekosistem memberi sumbangan hara sangat besar pada tanah. Tanaman memberikan masukan bahan organik melalui serasah yang tertimbun di permukaan tanah berupa daun dan ranting serta cabang yang jatuh. Bagian akar tanaman memberikan masukan bahan organik melalui akar-akar dan tudung akar yang mati serta dari eksudasi akar. Bahan organik merupakan salah satu penyusun tanah yang sangat penting bagi ekosistem tanah yaitu sebagai sumber dan pengikat hara serta substrat bagi fauna tanah (Suin, 2006).

Mesofauna tanah merupakan bagian dari keanekaragaman hayati yang memiliki peran penting dalam tanah terutama sebagai dekompositor dalam suatu ekosistem. Mesofauna tanah selain sebagai dekomposisi mampu mengubah bahan organik menjadi bahan anorganik yang dibutuhkan tumbuhan, juga memiliki arti penting dalam menjaga sifat fisik, kimia dan biologis tanah (Adianto, 1993), sehingga beberapa peneliti menjadikan mesofauna tanah sebagai bioindikator kondisi lingkungan (Suwondo, 1996).

Vegetasi dan mesofauna tanah dalam suatu ekosistem memiliki hubungan yang erat dan kontinyu, kedudukan berada pada awal dan akhir dalam suatu hubungan yang disebut rantai makanan. Hubungan tersebut terdiri dari produsen, konsumen (herbivora, karnivora, dan omnivora dan detritivora (pengurai) yang mengambil peran penting dalam keseimbangan lingkungan (Primack, Supriatna, Indrawan, Kramadibrata.1998). Keberadaan mesofauna tanah dipengaruhi oleh banyak faktor diantaranya adalah keberadaan 
vegetasi yang ada diatasnya. Vegetasi sebagai input makanan bagi kehidupan mesofauna di dalam tanah, semakin tinggi jenis dan jumlah input makanan yang dihasilkan oleh tumbuhan maka semakin beragam juga jenis mesofauna tanah yang hidup dan semakin tinggi pula populasi mesofauna tanah. Sampai saat ini belum ada informasi mengenai keragaman

\section{METODE PENELITIAN}

Penelitian ini dilakukan di beberapa habitat vegetasi pada zone pemanfaatan intensif di kawasan Taman Nasionl Kelimutu dan laboraturium fakultas Pertanian Universitas Flores, Kabupaten Ende. Penelitian ini dilaksanakan selama 6 bulan yaitu dari bulan Oktober 2010 - Maret 2011.

Bahan-bahan yang digunakan dalam penelitian ini adalah Alkohol $70 \%$, Aquades dan kertas label.

Alat yang digunakan dalam kegiatan penelitian yaitu rol meter, mikroskop, pinset, $\mathrm{pH}$ meter, higro meter, kaca pembesar, pipa pengebor tanah, kantong kain, botol koleksi, cawan petri, modifikasi corong berlesse, lampu 15 watt, tali rafia, sarung tangan, GPS garmin, kamera digital, alat tulis, kalkulator, kuas dan kunci determinasi serangga.

Penelitian ini dirancang dengan metode jalur dan sampling pada beberapa habitat vegetasi di kawasan Taman Nasional Kelimutu pada zone pemanfaatan intensif yaitu

1. Vegetasi VR : (Vaccinium varingiaefolium dan Rhododendron renschianum) disebut sebagai stasiun I

2. Vegetasi VCa : hutan Campuran disebut sebagai stasiun II

3. Vegetasi VC : hutan Camara disebut sebagai stasiun mesofauna tanah di kawasan Taman Nasional Kelimutu. Sehingga penelitian tentang "Studi Keragaman Mesofauna Tanah Pada Beberapa Habitat Vegetasi Di Kawasan Taman Nasional Kelimutu". dianggap penting yang selanjutnya akan digunakan sebagai informasi dasar dalam melakukan pengembangan dan pengelolaan kawasan kedepannya

IIIPengamatan dan pengambilan data vegetasi dilakukan dengan membuat petak pengamatan dengan metode nested sampling, plot berukuran $20 \mathrm{~m}$ $x 20 \mathrm{~m}$ untuk pohon, $10 \mathrm{~m} \times 10 \mathrm{~m}$ untuk tiang, $5 \mathrm{~m} \times 5 \mathrm{~m}$ untuk pancang, dan $2 \mathrm{~m} \times 2 \mathrm{~m}$ untuk semai dan tumbuhan bawah (Kusmana 1997).

Sedangkan untuk pengamatan dan pengambilan data mesofauna tanah dilakukan pengambilan sampel tanah pada setiap stasiun pengamatan dengan metode Neuman dan pemisahan mesofauna tanah dari tanah dan serasah dengan menggunakan corong Barlese (Handayanto 1996) selanjutnya kegiatan identifikasi mesofauna tanah di labolaturium dengan menggunkn kunci determinasi serangga.

Pengambilan data dilakukan secara acak pada setiap stasiun dengan 3 kali ulangan.

Variabel pengamatan yang ditetapkan meliputi :

1. Analisis Vegetasi

Analisis vegetasi bertujuan untuk mempelajari dan mengetahui susunan (komposisi jenis) dan bentuk struktur vegetasi (Indriyanto 2005)

a. Kerapatan Relatif (KR)

Kerapatan merupakan jumlah individu per unit luas atau per unit volume. Dengan kata lain, kerapatan merupakan jumlah individu organisme per satuan 
ruang. Untuk kepentingan analisis digunakan rumus sebagai berikut.

b. Dominansi (D)

$D=\quad \frac{\text { Jumlah Bidang dasar suatu jenis }}{\text { Luas petak contoh }}$

d. Keragaman vegetasi

Untuk mengetahui indeks keragaman vegetasi pada suatu kawasan hutan menggunakan rumus Shannon index of general diversity dengan rumus :

$\mathrm{H}^{\prime}=-\Sigma($ pi $\ln \mathrm{pi})$

Keterangan:

$\mathrm{H}^{\prime}=$ Indeks keanekaragaman jenis

pi $=$ proporsi dari tiap spesies

2. Keragaman jenis mesofauna yang ditemukan pada setiap jenis vegetasi

Keragaman jenis ditentukan dengan menggunakan rumus Shannon Index of General Diversity (Misra, 1980), dengan rumus sebagai berikut:

$\mathrm{H}^{\prime}=-\Sigma($ pi $\ln$ pi $)$

Keterangan:

$\mathrm{H}^{\prime}=$ Indeks keragaman jenis

pi $=$ proporsi dari setiap spesies

menurut Magurran, 1988 dalam Rahmawaty, 2000 indeks keragaman jenis ( H' ) berkisar antara 1,5 - 3,5

$1,5 \quad$ : Nilai keragaman rendah 1,5-3,5 : Nilai keragaman sedang 3,5 : Nilai keragaman tinggi

Untuk mendapatkan nilai indeks keragaman mesofauna tanah, terlebih dahulu melakukan identifikasi, kemudian menghitung populasi mesofauna tanah pada setiap stasiun, selanjutnya mencari nilai keragaman setiap jenis mesofauna

$$
\mathrm{KR}=\frac{\text { Kerapantan satu jenis }}{\text { Kerapatan seluruh jenis }} \times 100 \%
$$

$$
\text { Dominasi suatu jenis . }
$$

$\mathrm{DR}=$

Dominasi seluruh contoh

$X 100 \%$

tanah yang di temukan dan selanjutnya mendapatka nilai indeks keragaman mesofauna tanah per stasiun.

3. Dominansi mesofauna tanah pada setiap jenis vegetasi (\%)

Nilai indeks dominansi mesofauna tanah mencerminkan tingkat kemerataan jenis dalam suatu populasi jika nilai Dominansi mendekati 1, maka kemerataan jenisnya semakin tinggi. Kemerataan jenis ditentukan dengan menggunakan rumus indeks kemerataan (E), sebagai berikut (Krebs, 1978):

$\mathrm{E}=\frac{\mathrm{H}^{\prime}}{\mathrm{In} \mathrm{S}}$

Keterangan:

$\mathrm{E}=$ Indeks Dominansi

$\mathrm{H}^{\prime}=$ Indeks keanekaragaman jenis

$\mathrm{S}=$ Jumlah jenis

4. Suhu permukaan tanah dan suhu tanah $\left({ }^{\circ} \mathrm{C}\right)$

Data suhu tanah digunakan sebagai indikator ada atau tidaknya aktivitas mesofauna di dalam tanah. Kegiatan pengambilan data suhu permukaan dan suhu tanah dilakukan pada setiap titik pengamatan yang selanjutnya di ambil rata-rata setiap petaknya

Kegiatan explorasi dan survey habitat dilakukan untuk mendapatkan gambaran tentang kemungkinan jenis 
mesofauna tanah yang akan ditemukan di lapangan berdasarkan jenis vegetasi penutupan lahan yang ada di Kawasan Taman Nasional Kelimutu. Perbedaan vegetasi menjadi penentu utama terkait dengan habitat yang disukai oleh berbagai jenis mesofauna tanah. Dari hasil explorasi ditentukan lokasi yang akan menjadi stasiun pengambilan sampel. Stasiun pengambilan sampel yang ditentukan berdasarkan jenis vegetasi

\section{Pengambilan data vegetasi}

a Membuat petak pengamatan dengan metode nested sampling, dengan ukuran $20 \mathrm{~m} \times 20 \mathrm{~m}$ untuk pohon, $10 \mathrm{~m} \times 10 \mathrm{~m}$ untuk tiang, $5 \mathrm{~m} x 5 \mathrm{~m}$ untuk pancang, dan $2 \mathrm{~m} \times 2$ m untuk semai dan tumbuhan bawah (Kusmana 1997). Klasifikasi pohon $\varnothing>20 \mathrm{~cm}$, tiang $\varnothing 10-20 \mathrm{~cm}$, pancang $\varnothing<10$ atau tinggi $\geq 5 \mathrm{~m}$ dan semai tinggi $\leq 5 \mathrm{~m}$

a. Data vegetasi yang di catat untuk keperluan analisa vegetasi adalah diameter pohon dan tiang, luas bidang datar tumbuhan bawah, pancang dan semai serta jumlah setiap jenis.

\section{Pengambilan sampel tanah dilapang}

Pengambilan sampel tanah dilakukan berdasarkan metode Neuman dengan langkah-langkah pelaksanaan sebagai berikut :

a. Membuat petak pengamatan pada 3 (tiga) jenis vegetasi yang berbeda yang akan diteliti, setiap stasiun penelitian dibuat 3 (tiga) petak dengan ukuran petak $20 \mathrm{~m} \times 20 \mathrm{~m}$, dimana tiga petak terdiri dari 5 (lima) titik pengambilan sampel. Petak pertama ditentukan secara acak dan proporsional. Untuk ulangan selanjutnya ditentukan dengan arah diagonal. Setiap ulangan memiliki rentang jarak $200 \mathrm{M}$.

b. Pengambilan sampel tanah disetiap titik menggunakan pipa berdiameter $7 \mathrm{~cm}$ pada kedalaman yang berbeda yaitu $0-30 \mathrm{~cm}$ dengan asumsi bahwa mesofauna tanah dapat hidup dan berada pada kedalaman tersebut dengan ketebalan humus tanah berkisar $20 \quad-30$ $\mathrm{cm}$.

c. Sampel tanah dari setiap titik dikomposit berdasarkan kedalaman tanah, sehingga setiap stasiun terdapat 3 (tiga) sampel sampel tanah yang sudah dikomposit dengan kedalaman $0-30 \mathrm{~cm}$.

d. Selanjutnya sampel tanah yang telah dipisahkan dalam kantong kain dan diberi label dibawa ke laboraturium untuk dipisahkan antar tanah dengan mesofauna tanah

\section{Pengamatan di laboraturium}

Tanah yang diambil di lapangan selanjutnya akan diekstraksi menggunakan metode Dinamik (corong Barlesse-tullgren) dengan tahapan sebagai berikut:

a. Tanah yang sudah siap disimpan pada wadah berlesse dan ditutupi kain kasa selanjutnya diletakkan di atas tabung koleksi yang telah terisi alkohol $70 \%$ sebanyak $20 \mathrm{cc}$.

b. Sampel disinari dengan lampu yang berkekuatan 15 watt dengan lama penyinaran $5 \quad$ s/d 8 hari agar mesofauna tanah terpisah dari tanah. Alat pemisah tabung berlesse modifikasi dapat dilihat pada gambar 3.7.

c. Mesofauna tanah yang telah terpisah dan jatuh kedalam botol koleksi identifikasi di bawah mikroskop dengan cara mencocokkan ciri-ciri berdasarkan kunci determinasi serangga.

Analisis Data

Analisa data dilakukan dengan membandingkan data mesofauna tanah pada setiap habitat vegetasi dan data vegetasi berupa nilai indeks keragaman, 
(Dominansi) kemerataan jenis (Misra, 1980 dan Indriyanto 2005)

\section{HASIL DAN PEMBAHASAN}

Kegiatan penilitian keragaman mesofauna tanah ini dilaksanakan pada tiga stasiun, dimana diasumsikan sebagai keterwakilan kawasan di sekitar Danau Kelimutu. Stasiun yang menjadi keterwakilan diantaranya stasiun I adalah Vegetasi VR : (Vaccinium varingiaefolium ) dan Rhododendron renschianum), stasiun II adalah Vegetasi $\mathrm{VCa}$ (rimba campuran) dan stasiun III Vegetasi VC : hutan cemara (Casuarina junghuniana).

Berdasarkan hasil penelitian mesofauna tanah pada beberapa habitat vegetasi di Kawasan Taman Nasional Kelimutu menunjukkan perbedaan keragaman dan kemerataan jenis mesofauna tanah yang berbeda baik dalam jumlah maupun jenisnya.

\section{Keragaman Vegetasi}

Vegetasi yang tumbuh pada suatu lokasi merupakan sumber energi pertama bagi kehidupan makhluk hidup yang ada di alam. Sebagai pemasok energi pertama diantaranya energi untuk kehidupan mesofauna tanah. Vegetasi yang tumbuh di alam membentuk ekosistem tertentu dengan menciptakan iklim mikro yang spesifik.

Vegetasi sebagai pemasok energi untuk kehidupan baik yang di ambil langsung dari tumbuhan ataupun berupa serasah dan sisa-sisa tumbuhan yang telah mati merupakan sumber energi bagi kehidupan mesofauna tanah yang hidup dibawahnya.
Analisis Vegetasi merupakan suatu cara untuk mempelajari susunan atau komposisi jenis dan bentuk atau struktur vegetasi (Indriyanto 2005). Tabel berikut memperlihatkan hasil analisa kerapatan relatif, dominansi dan dominansi relatif jenis vegetasi pada setiap stasiun pengamatan. 
Fendra: Studi keragaman mesofauna tanah

Tabel 1. Jenis Tumbuhan, Jumlah Individu, Kerapatan Relatif, Dominansi, Dominansi Relatif dan Keragaman Vegetasi pada Stasiun I

\begin{tabular}{clcccc}
\hline No & \multicolumn{1}{c}{ Jenis Tumbuhan } & Jml. Individu & Kerapatan Relatif (\%) & Dominansi & Dominansi Relatif (\%) \\
\hline 1 & Vaccinium varingiafolium & 133 & 52.99 & 0.4552 & 43.85 \\
2 & Rhododendron renschianum & 87 & 34.66 & 0.288 & 27.74 \\
3 & Casuarina junghuhniana & 4 & 1.59 & 0.0375 & 3.61 \\
4 & Albizi Montana & 6 & 2.39 & 0.0375 & 3.61 \\
5 & Melastoma polyanthum & 5 & 1.99 & 0.0541 & 5.21 \\
6 & Gleichenia lineris & 11 & 4.38 & 0.0638 & 6.15 \\
7 & Pteris Sp & 3 & 1.20 & 0.0476 & 4.58 \\
8 & Crex baccans & 2 & 0.80 & 0.0545 & 5.25 \\
\hline & Jumlah & & & \\
\hline & Keragaman jenis (indeks & $\mathbf{2 5 1}$ & $\mathbf{1 . 1 6 5}$ & & \\
\hline
\end{tabular}

Tabel 2 Jenis Tumbuhan, Jumlah Individu, Kerapatan Relatif, Dominansi, Dominansi Relatif dan Keragaman Vegetasi pada Stasiun II

\begin{tabular}{clcccc}
\hline No & \multicolumn{1}{c}{ Jenis Tumbuhan } & Jumlah Individu & Kerapatan Relative (\%) & Dominansi & $\begin{array}{c}\text { Dominansi Relatif } \\
(\%)\end{array}$ \\
\hline 1 & Wendlandia paniculata & 7 & 2.58 & 0.1141 & 4.31 \\
2 & Tebernaemontana sphaerocarpa & 4 & 1.48 & 0.125 & 4.73 \\
3 & Casuarina junghuhniana & 1 & 0.37 & 0.1 & 3.78 \\
4 & Schefflera lucida & 8 & 2.95 & 0.1616 & 6.11 \\
5 & Vernonia arborea & 3 & 1.11 & 0.075 & 2.84 \\
6 & Omalantus giganteus & 3 & 1.11 & 0.0925 & 3.50 \\
7 & Ficus variegate & 2 & 0.74 & 0.05 & 1.89 \\
8 & Glocidion philipicu & 3 & 1.11 & 0.1241 & 4.69 \\
9 & Pittosporum molucnum & 4 & 1.48 & 0.0416 & 1.57 \\
10 & Suregada Sp & 5 & 1.85 & 0.0375 & 1.42 \\
11 & Ciatea contaminant & 28 & 10.33 & 0.1875 & 7.09 \\
12 & Melastoma polyanthum & 4 & 1.48 & 0.0433 & 1.64 \\
13 & Litsea resinosa & 150 & 55.36 & 0.06 & 33.65 \\
14 & Macaranga giganteus & 5 & 1.85 & 0.1275 & 4.82 \\
15 & Litsea Sp & 16 & 5.90 & 1.66 & 2.36 \\
16 & Prunus Arborea & 12 & 4.43 & 0.2175 & 8.22 \\
17 & Begonia Kelimutuensis & 2 & 0.74 & 0.1166 & 4.41 \\
18 & Evodia latifolia & 1 & 0.37 & 0.0075 & 0.28 \\
19 & Ficus fistulosa & 1 & 0.37 & 0.0641 & 2.42 \\
20 & Ardisia javanica & 12 & 4.43 & 0.0066 & 0.25 \\
\hline & Jumlah & $\mathbf{2 7 1}$ & & & \\
\hline & Keragaman jenis (indeks & $\mathbf{1 . 8 2 1}$ & & & \\
\hline & Shannon) & & & & \\
\hline
\end{tabular}


Fendra: Studi keragaman mesofauna tanah

Tabel 3. Jenis Tumbuhan, Jumlah Individu, Kerapatan Relatif, Dominansi, Dominansi Relatif dan Keragaman Vegetasi pada Stasiun III

\begin{tabular}{|c|c|c|c|c|c|}
\hline No & Jenis Tumbuhan & $\begin{array}{l}\text { Jumlah } \\
\text { individu }\end{array}$ & $\begin{array}{l}\text { Kerapatan } \\
\text { relatif }(\%)\end{array}$ & Dominansi & $\begin{array}{l}\text { Dominansi } \\
\text { Relatif (\%) }\end{array}$ \\
\hline 1 & Casuarina junghuhniana & 46 & 12.2 & 0.081 & 12.07 \\
\hline 2 & Melastoma polyanthum & 15 & 4.0 & 0.0012 & 0.18 \\
\hline 3 & Eupatorium odoratum & 300 & 79.6 & 0.3991 & 59.48 \\
\hline 4 & Gleichenia liniearis & 5 & 1.3 & 0.1012 & 15.08 \\
\hline 5 & Carex baccans & 4 & 1.1 & 0.0008 & 0.12 \\
\hline 6 & Cyatea contaminant & 5 & 1.3 & 0.0051 & 0.76 \\
\hline 7 & Omalantus giganteus & 1 & 0.3 & 0.0001 & 0.01 \\
\hline 8 & Pteris $S p$ & 5 & 1.3 & 0.01 & 1.49 \\
\hline 9 & Rubus moluccanus & 2 & 0.5 & 0.06 & 8.94 \\
\hline \multirow[t]{3}{*}{10} & Setaria palmifolia & 2 & 0.5 & 0.0125 & 1.86 \\
\hline & Jumlah & 385 & 100 & 0.671 & 100 \\
\hline & $\begin{array}{l}\text { Keragaman jenis (indeks } \\
\text { Shannon) }\end{array}$ & 0.861 & & & \\
\hline
\end{tabular}

Pada stasiun I ditemukan jenis Vaccinium varingiafolium dengan kerapatan relatif $52,99 \%$ dengan dominansi relatif $43,85 \%$ dan jenis Rhododendron renschinum kerapatan relatif $34,66 \%$ dengan dominansi relatif $27,74 \%$ artinya pada stasiun I vegetasi yang membentuk habitat mesofauna tanah didominasi oleh dua jenis vegetasi seperti terlihat pada table 1 Keadaan ini membentuk suatu ekosistem dan iklim yang khas. Hal tersebut di duga keberadaan stasiun I dekat dengan kawah danau Kelimutu yang mengeluarkan hawa belerang dan memiliki ketinggin tempat $1.589 \mathrm{~m} \mathrm{dpl}$, sehingga hanya beberapa jenis vegetasi yang mampu hidup dan beradaptasi dengan lingkungan.
Vaccinium dan Rhododendron merupakan tumbuhan pionir yang tumbuh soliter dan tumbuh mengumpul membentuk rumpun selain dapat menciptakan iklim sendiri untuk mengurangi penguapan tanah. Biomassa tanaman berupa serasah, yang jatuh berupa daun dapat terkumpul di bawah tajuk atau di sekitar rumpun tanaman yang merupakan sumber makanan bagi mesofauna tanah. Keberadaan vegetasi pada stasiun I memberi gambaran bahwa pasokan unsur hara yang masuk ke dalam tanah berupa serasah rendah yang akan berpengaruh pada keberadaan mesofauna tanah yang hidup di bawahnya.

Nilai indeks keragaman jenis vegetasi pada stasiun I adalah 1,165 
terlihat pada tabel 4.1 dapat diartikan bahwa keragaman vegetasi pada stasiun I rendah.

Stasiun II terlihat pada tabel 4.2 memberi gambaran komposisi vegetasi yang suatu ekosistem lebih beragam dan jumlah individu yang tinggi mencapai 271 individu dengan nilai indeks keragaman vegetasi ( $\mathrm{H}^{\prime} \quad$ : 1,821) menunjukkan bahwa keragaman vegetasi pada stasiun II adalah sedang. Keadaan ini memungkinkan jumlah dan beragamnya input unsur hara berupa serasah dan sisa-sisa bagian tanaman. Semakin besar input yang masuk ke tanah maka semakin besar juga ketersediaan bahan organik tanah.

Bagian-bagian tumbuh yang mati masuk ke dalam tanah sehingga menyediakan makanan dan energi mesofauna tanah dan mikroflora. Akarakar tumbuhan meningkatkan agregasi tanah, dan karena akar menembus ke lapisan tanah yang dalam, maka bila membusuk menjadi sumber humus, tidak hanya dilapisan atas tetapi juga di lapisan yang lebih dalam. Sumber humus untuk lapisan atas tanah terutama berasal dari sisa-sisa tumbuhan yang jatuh ke permukaan tanah (Hardjowigeno, 2007).

Pada stasiun II keberadaan vegetasi dari jenis Litsea resinosa dengan dominansi reltif $33.65 \%$ lebih keberadaannya lebih mendominasi dari jenis vegetasi yang lain seperti Prunus arborea, schefflera lucida dan litsea sp keberadaanya merata. Jenis Litsea resinosa dari Famili Lauracee merupkan jenis vegetasi yang berdaun lebar dengan perkembangbiakan dengan biji yang memiliki perkecambahan yang cepat memungkainkan perkembangngannya cepat sehingga kerapatan relatif $55.36 \%$.

Pada vegetasi hutan cemara yaitu pada stasiun III terlihat pada tabel 4.3 merupakan lokasi hutan dengan komposisi vegetasi yang tersusun dari tegakan Casuarinas junghuniana dan beberapa jenis pohon. Morfologi jenis Casuarinas junghuniana memiliki tutupan kanopi yang tipis dikarenakan jenis ini berdaun jarum. Sehingga pada lokasi ini intensitas cahaya yang masuk ke lantai hutan lebih banyak dan memungkinkan tumbuhan penutup tanah dapat tumbuh dan berkembang dengan baik. Jenis Eupatorium odoratum merupakan tanaman bawah dominan yang di temukan pada stasiun III. Jenis Eupatorium odoratum ditemukan 300 individu nilai dengan kerapatan relatif 79,6 .

Keragaman vegetasi indeks Shannon pada stasiun III ( $H^{\prime}$ : 0,861) berarti keragaman vegetasi pada stasiun III rendah. Hal ini di sebabkan keberadaan vegetasi dari jenis Casuarina junghuniana dan Eupatorium odoratum merupakan jenis vegetasi yang mempunyai zat alelopati sehingga tanaman dari jenis lain tidak bisa tumbuh di sekitarnya, kalaupun tumbuh akan kerdil atau pertumbuhannya lambat.

Keberadaan Vegetasi selain sebagai sumber energi berupa pasokan mulsa ke dalam tanah, keberadaan vegetasi juga berpengaruh terhadap pembentukan iklim mikro, keadaan sifat fisik tanah, dan sifat kimia tanah berupa $\mathrm{pH}$ tanah dan kandungan Bahan organik tanah.

Kerapatan vegetasi berupa jumlah individu pada suatu habitat dengan di 
Fendra: Studi keragaman mesofauna tanah

dukung ketebalan kanopi akan udara, kelembaban membentuk iklim mikro berupa suhu udara dan juga berpengaruh pada suhu dan $\mathrm{pH}$ tanah. Keadaan suhu tanah dapat dijadikan indikator kemungkinan ada atau tidaknya kehidupan mesofauna tanah pada suatu lokasi.

Keragaman Mesofauna Tanah

Keanekaragaman mesofauna tanah pada beberapa vegetasi di Kawasan Taman Nasional Kelimutu memberi informasi mengenai jenis mesofauna tanah yang di temukan dibeberapa stasiun pengamatan.

Tabel 4 Jenis mesofauna tanah, jumlah indivdu, keragaman jenis, indeks keragaman jenis Indeks Shannon dan indeks kemerataan jenis mesofauna tanah pada 3 (tiga) stasiun

\begin{tabular}{|c|c|c|c|}
\hline Stasiun & Jenis mesofauna tanah & Jumlah individu & Keragaman jenis \\
\hline \multirow[t]{8}{*}{ I } & Anurida maritima & 1 & 0.10 \\
\hline & Deuterosma thurusphalipes & 1 & 0.10 \\
\hline & Diplura & 4 & 0.24 \\
\hline & Phaedole spp & 18 & 0.35 \\
\hline & Stahylinidae & 13 & 0.37 \\
\hline & Jumlah & 37 & \\
\hline & Indeks keragaman jenis & 1.153 & \\
\hline & Indeks kemerataan jenis & 0.72 & \\
\hline \multirow[t]{10}{*}{ II } & Anurida granaria & 25 & 0.33 \\
\hline & Anurida maritima & 32 & 0.35 \\
\hline & Bolobella aurantica & 11 & 0.22 \\
\hline & Dicyrtoma daundersi & 2 & 0.07 \\
\hline & Phaedole spp & 31 & 0.35 \\
\hline & Sheratophy bengtssoni & 16 & 0.27 \\
\hline & Sheratophy sellaarmata & 4 & 0.11 \\
\hline & Jumlah & 122 & \\
\hline & Indeks keragaman jenis & 1.771 & \\
\hline & Indeks kemerataan jenis & 0.85 & \\
\hline \multirow[t]{10}{*}{ III } & Anurida granaria & 35 & 0.36 \\
\hline & Chilopoda & 12 & 0.23 \\
\hline & Deuterosma thurusphalipes & 27 & 0.33 \\
\hline & Dicyrtoma daundersi & 15 & 0.26 \\
\hline & Dicyrtoma fusca & 22 & 0.31 \\
\hline & Phaedole spp & 35 & 0.36 \\
\hline & Sheratophy sellaarmata & 4 & 0.11 \\
\hline & Jumlah & 146 & \\
\hline & Indeks keragaman jenis & 1.727 & \\
\hline & Indeks kemerataan jenis & 0.28 & \\
\hline
\end{tabular}

Keterangan : Jenis mesofauna tanah yang dtemukan pada 3 Stasiun pengamatan terlampir. 
Hasil pengambilan sampel tanah pada tiga stasiun penelitian ditemukan 12 jenis spesies, dengan rincian pada stasiun I ditemukan 5 jenis spesies, stasiun II ditemukan 7 jenis spesies dan pada stasiun III ditemukan 6 jenis spesies. Keberadaan mesofauna tanah pada setiap stasiun penelitian, jenis mesofauna tanah yang ditemukan pada setiap stasiun berbeda namun ada beberapa jenis mesofauna tanah dapat ditemukan pada setiap stasiun diantaranya dari jenis Phaedole spp. Hal ini disebabkan faktor lingkungan baik faktor abiotik berupa sifat fisik dan kimia tanah juga disebabkan oleh faktor biotik berupa keberadaan vegetasi dan organisme lainnya.

Tabel 4 dapat dilihat nilai keragaman mesofauna tanah tertinggi terdapat pada stasiun II adalah jenis Anurida maritima jumlah individu 32 dengan nilai keragaman 0,35 dan jenis Phaedole spp jumlah individu 32 dengan nilai keragaman 0,35 . Pada posisi kedua pada stasiun III dengan jenis Anurida granary jumlah individu 35 dengan nilai keragaman 0,34 dan terendah pada stasiun pengamatan I dari jenis Phaedole spp jumlah individu 18 dengan nilai keragaman 0,35.

Keragaman mesofauna tanah dipengaruhi oleh keadaan lingkungan setiap stasiun berbeda. Eksistensi kelompok mesofauna tanah pada suatu habitat sangat tergantung pada kondisi lingkungannya (Suin, 1996). Keragaman vegetasi seperti pada tabel 1 yang ada pada setiap stasiun pengamatan menjadi salah satu faktor penting mendukung keragaman mesofauna tanah di suatu lokasi.
Keragaman mesofauna tanah (indeks Shannon) yang terlihat pad tabel 4.4 menggambarkan tingkat keragaman mesofauna tanah pada pada stasiun I dengan nilai indeks keragaman jenis 1,153 dapat diartikan keragaman rendah sedangkan pada stasiun II dan stasiun III dengan nilai indeks Shannon keragaman jenis 1,771 dan 1,727 dapat diartikan keragaman mesofauna sedang. Pengelompokkan data ini di dasarkan pada nilai indeks Keragaman (H') berkisar antara 1,5 - 3,5 dengan interval Nilai keragaman rendah $\left(\mathrm{H}^{\prime}<1,5\right)$, Nilai keragaman sedang ( $H^{\prime}: 1,5$ - 3,5 ) dan Nilai keragaman tinggi ( $\mathrm{H}^{\prime}>3,5$ ).

Nilai indeks Shannon keragaman mesofauna tanah memperlihatkan keterhubungan antara keadaan lingkungan berupa keragaman vegetasi dengan keragaman mesofauna tanah dan pada akhirnya berpengaruh pada perkembangan profil tanah. Keragaman mesofauna tanah (Indeks Shannon) semakin tinggi berarti tingkat dekomposisi yang terjadi akan semakin tinggi dan sebaliknya tingkat dekomposisi akan rendah jika indeks keragaman mesofauna tanah rendah (Suwondo 2002). Indeks keragaman tinggi berarti tingkat kesuburan tanah tinggi yang ditandai dengan tekstur tanah yang lempung, top soil yang tebal dan kandungan bahan organik yang tinggi.

Untuk kawasan Taman Nasional Kelimutu keragaman mesofauna yang ditemukan pada stasiun penelitian menunjukkan keragaman mesofauna tanah dari sedang ke rendah. Faktor yang sangat berpengruh terhadap keberadaan mesofauna tanah adalah keadaan lingkungan setempat. Beberapa faktor lingkungan yang menjadi variabel 
pengamatan diantaranya adalah ( Suin 2006):

1. Faktor abiotik berupa sifat fisik (suhu tanah, tekstur dan jenis tanah, porositas tanah dan kelembaban udara) dan kimia tanah $(\mathrm{pH}$, kandungan bahan organik dan unsurusur hara tanah).

2. Faktor biotik berupa keberadaan vegetasi, mikroflora dan organism lainnya pada lingkungan tersebut. keberadaan mesofauna tanah rendah, Jenis tanah dalam kawasan terdiri dari Regosol, Mediteran dan Latosol. Tanah Regosol paling dominan persebarannya dalam kawasan $\mathrm{TN}$ Kelimutu ini. Pada beberapa lokasi terdapat tanah pasir yang merupakan endapan vukanik. Tanah pasir ini bersifat padat sehingga memiliki daya tahan yang besar untuk menerima tekanan yang berat (Aristan Ekawasta, 1991).

Pada stasiun I memiliki keragaman mesofauna rendah menggambarkan tingkat dekomposisi bahan organik yang terjadi pada stasiun I rendah. Keadaan seperti ini disebabkan keberadaan vegetasi yang kurang dan bersifat homogen dan berpengruh terhadap sumber bahan organik berupa serasah dari vegetasi diatasnya kurang. Kurangnya vegetasi yang tumbuh pada stasiun I mengakibatkan input hara ke tanah menjdi berkurang. Faktor lain yang mempengaruhi keberdaan mesofauna tanah adalah jenis tanah yang ada pada stasiun I berupa bebatun pasir yang merupakan endapan vulkanik yang bersifat padat (Arista 1991). Selain faktor fisik tanah, faktor kimia tanah berupa $\mathrm{pH}$ tanah dan kandungan bahan organik tanah berupa unsur hara juga bepengaruh terhadap keberdaan mesofauna tanah (data analisis tanah terlampir). Selain itu terjadinya erosi permukaan dimana unsur hara yang ada hanyut terbawa aliran permukaan mengakibatkan kehilangan hara. Kurangnya vegetasi yang tumbuh pada stasiun I diduga karena adanya hembusan hawa belerang dari kawah danau Kelimutu.

Keragaman mesofauna pada stasiun II dan stasiun III dengan nilai indeks keragaman (indeks Shannon) adalah : 1,771 dan 1,727 menunjukkan keragaman sedang. Faktor yang mempengaruhi keberdaan mesofauna tanah pada dua stasiun ini dikarenakan memiliki populasi vegetasi lebih banyak dan lebih beragam sehingga dapat menyumbangkan bahan organik berupa serasah ke dalam tanah lebih beragam. Secara umum ekosistem yang terbentuk pada stasiun II berupa ekosistem hutan rimba campuran. Keberadaan vegetasi ini memberi pasokan makanan bagi kehidupan di bawahnya termasuk mesofauna tanah.

Keadaan vegetasi pada stasiun III seperti tabel 3 yaitu hutan tutupan yang didominasi oleh vegetasi cemara (Casuarina junghuniana) merupakan jenis tumbuhan berdaun jarum yang memungkinkan cahaya matahari tembus ke lantai hutan. Jenis tumbuhan bawah didominasi oleh kirinyu (Eupatorium odoratum) dan beberapa jenis rumput. Keberadaan tumbuhan bawah yang ada di stasiun III memungkinkan mensuplai biomassa ke dalam tanah lebih cepat dikarenakan serasah jenis ini lebih cepat terkomposisi dan baik untuk perkembangan mesofauna tanah yang ada di bawahnya. Vegetasi rumput-rumputan mampu menyediakan biomassa lebih cepat dengan jumlah yang banyak sepanjang tahun dibandingkan dengan 
vegetasi berkayu. Vegetasi rumputrumputan mengandung kadar bahan organik tanah lebih tinggi 30\% dari daripada tanah hutan.

Pada stasiun III merupakan perjumpaan terbanyak dari 3 mesofauna yang ditemukan dengan jumlah 146 individu,. Jenis mesofauna tanah yang ditemukan diantaranya Anurida granaria , Phaedole spp, Deuterosma thurusphalipes

Keragaman mesofauna tanah pada berbagai keadaan lahan disebabkan oleh adanya keragaman jenis dan keadaan tumbuhan penutup tanah, sifat fisik dan kimia tanah (Purwowidodo dan Wulandari 1998, Latifah 2002). Sifat fisik dan kimia tanah berupa suhu, kelembaban, porositas tanah dan $\mathrm{pH}$ tanah serta bahan organik tanah merupakan faktor pendukung habitat bagi mesofauna tanah. Pada stasiun II memiliki suhu tanah rata-rata 19.504. semakin tingggi suhu tanah semakin tinggi aktivitas proses dekomposisi bahan organik organisme tanah.

Pada stasiun II dan III memiliki kandungan bahan organik yang tinggi dengan kandungan unsur-unsur hara yang proporsional (Data analisis tanah terlampir), merupakan tempat yang baik hidup dan berkembangnya mesofauna tanah.

Pada tabel 4 pada stasiun I, stasiun II maupun satsiun II, terlihat keberadaan mesofauna tanah merata, jenis mesofauna tanah ini diantaranya Phaedole Spp.

Phaedole Spp merupakan genus dari semut yang ekologinya cukup luas dan memiliki lebih dari seribu spesies. Mesofauna dari jenis ini dapat hidup dan memiliki kemampuan beradaptasi dengan lingkungan cukup tinggi.

Dari beberapa jenis mesofauna tanah yang ditemukan pada setiap stasiun penelitian, Phaedole spp meruakan jenis yang selalu hadir dalam setiap stasiun. Total individu yang ditemukan adalah 85 individu dari 3 (tiga) stasiun penelitian.

Phaedole Spp dapat menggali sejumlah besar tanah sehingga menyebabkan terangkatnya nutrisi tanah. Serangga-serangga tertentu memanfaatkan sarang semut dalam tanah sebagai tempat tinggal. Ini karena sarang semut menyediakan perlindungan yang relatif stabil dari fluktuasi kondisi lingkungan luar. Semut bersimbiosis dengan berbagai serangga, tumbuhan, dan fungi. Simbiosis ini saling menguntungkan dan mengambil beragam bentuk.

Salah satu faktor lingkungan yang sangat menentukan keberadaan semut adalah kelembaban lingkungan. Ukuran tubuh Phaedole Spp yang kecil membuat rasio antara luas permukaan dan volume tubuhnya bernilai besar. Hal ini menyebabkan penguapan air melalui permukaan tubuh besar dan cepat sehingga semut rentan terhadap kekeringan, terutama larva semut yang permukaan tubuhnya belum memiliki lapisan kutikula. Uap air lingkungan juga adalah sumber air yang dimanfaatkan semut untuk metabolisme tubuh. Karena hal-hal tersebut, semut lebih menyukai lingkungan lembab. Akan tetapi, lingkungan kering tidak selalu menjadi hambatan bagi semut, karena sebagian semut dapat memodifikasi lingkungan sekitar untuk disesuaikan dengan kebutuhan. Untuk mendapatkan tempat hidup yang tepat, sebagian semut dapat memodifikasi sarang untuk mendapatkan kelembaban yang diperlukan. Sebagian 
semut membentuk sarang di dalam tanah. Ini adalah salah satu cara mempertahankan kelembaban karena tanah menyimpan air dan menghambat penguapan akibat panas matahari. Pintu masuk lubang sarang ini seringkali membentuk kawah kecil atau cerobong.

\section{Kemerataan Jenis Mesofauna Tanah}

Indeks kemerataan jenis digunakan untuk mengetahui tingkat kemerataan kelimpahan individu antar jenis dan indeksnya terkait dengan indeks keragaman jenis $\left(\mathrm{H}^{\prime}\right)$. jika nilai indeks kemerataan jenis mendekati nilai 1 berarti kemertaan jenis mesofauna tanah tinggi. Interval nilai keragaman mesofauna tanah yang didapat di 3 (tiga) stasiun pengamatan berkisar antara 0,28 sampai dengan 0,85 . Nilai-nilai tersebut menunjukkan bahwa kemerataan jenis pada setiap stasiun sangat bervariasi. Indeks kemerataan jenis (E) tersebut dapat dilihat pada tabel 1

Peran vegetasi dalam menentukan atau sebagai indikator tingkat kemerataan jenis mesofauna tanah sangat besar. Vegetasi sebagai sumber bahan orgnik tanah yang merupakan makanan bagi mesofauna tanah.
Hubungan antara indeks keragaman vegetasi dengan indeks kemerataan jenis dapat terlihat pada gambar di 4.1

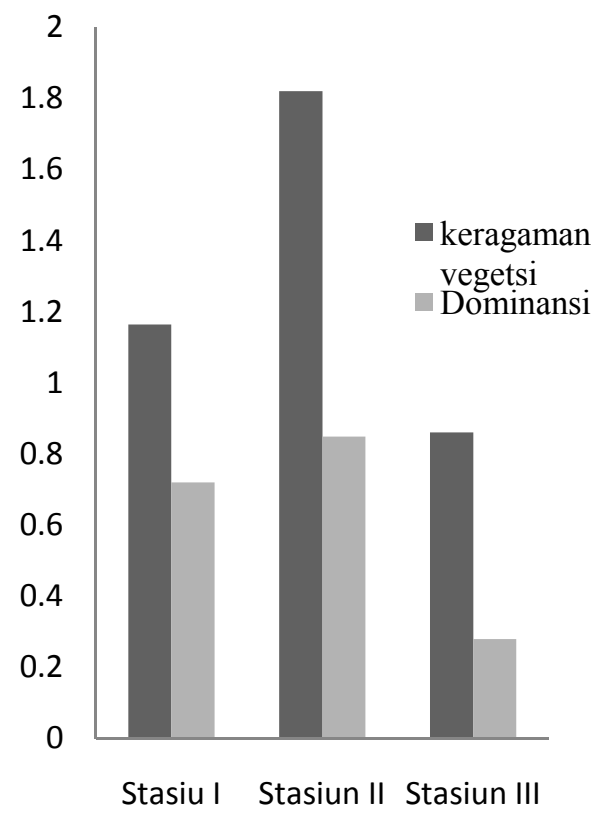

Gambar 1 Hubungan antara indeks keragaman vegetasi dengan dominansi mesofauna tanah

Gambar 1 menunjukkan bahwa dominansi mesofauna tanah berbanding lurus dengan indeks keragaan vegetasi. Semakin tinggi tingkat keragaman vegetasi maka semakin tinggi pula tingkat kemerataan jenis mesofauna tanah.

Dari hasil analisa, dapat dinyatakan bahwa semakin tingginya keanekaragaman vegetasi maka semakin tinggi tingkat kemerataan mesofauna tanahnya. Keragaman mesofauna tanah yang didukung oleh faktor-faktor tertentu, seperti suhu dan kelembaban. Komunitas fauna tanah sangat rumit, yang mempunyai komponen bawah tanah dan komponen atas tanah,dengan habitat makro dan mikro yang berubah secara tumpang tindih, yang memungkinkan 


\section{Kesimpulan}

Dari hasil penelitian dapat disimpulkan beberapa hal sebagai berikut :

1. Keragaman mesofauna tanah pada kawasan Taman Nasional Kelimutu adalah keragaman rendah s/d keragaman sedang. Keragaman rendah diperlihatkan pada vegetasi VR ditemukan 5 jenis mesofauna tanah $\left(\mathrm{H}^{\prime}: 1,153\right)$ sedangkan untuk keragaman sedang pada vegetasi $\mathrm{VCa}$ ditemukan 7 jenis mesofauna tanah $\left(\mathrm{H}^{\prime}\right.$ : 1,771) dan vegetasi VC ditemukan 6 jenis Mesofauna tanah (H': 1,727.)

2. Semakin tinggi keragaman vegetasi maka semakin tinggi dominansi mesofauna tanah di Kawasan Taman Nasional Kelimutu. Keragaman vegetasi tertinggi adalah (H': 1.821) diperlihatkan pada vegetasi $\mathrm{VCa}$ dengan dominansi mesofauna tanah adalah (E :0,85) pada vegetasi VR keragamn vegetasi adalah $\left(\mathrm{H}^{\prime}\right.$ : 1,771) dengan dominansi mesofauna tanah 0.72 dan pada vegetasi VC keragaman vegetasi adalah 0,861 dengan dominansi mesofauna tanah 0,28 .

\section{Ucapan terimah kasih}

Penelitian ini sangat bermanfaat bagi bagi masyarakat, khususnya sekitar kawasan Balai Taman Nasional Kelimutu (BTNK), Peneliti menyampaikan ucapan limpah terimakasih kepada Kepala BTNK atas kerjasamanya dan telah menjadi Sponsor dan semua pihak dalam mendukung penelitian ini.

\section{DAFTAR PUSTAKA}

Anonymous. 2006. Kajian Pelestarian

Danau Kelimutu dan Sekitarnya Kecamatan kelimutu,Kabupaten
Ende, Nusa Tenggara Timur. Balai Taman Nasional Kelimutu kerjasama dengan Pusat Penelitian Geoteknologi-LIPI. Bandung.

Anonymous. 2007. Studi Komunitas Flora dan Fauna Taman Nasional Kelimutu. Balai Taman Nasional Kelimutu kerjasama dengan Pusat Penelitian Biologi-LIPI Bogor. Bogor.

Ekaswasta A., PT 1991. Design Engineering Kelimutu. Propinsi Nusa Tenggara Timur. Buku 1. Data Dan analisis. Departemen Kehutanan

Suin, N. M. 2006. Ekologi Fauna tanah. Bumi Aksara. Jakarta.

Rahmawati. 2004. Studi Keanekaragaman Mesofauna Tanah di Kawasan Hutan Wisata Alam Sibolangit. Fakultas Pertanian-Universitas Sumatera Utara

Wulandari S.,Sugiyanto.,Wiryanto. 2005. Pengaruh Keanekaragaman Mesofauna dan Makrofauna Tanah Terhadap Dekomposisi Bahan Organik Tanaman di Bawah Tegakan Sengon (Paraserianthes falcataria). Bioteknologi 4(1): 20-27

Hilwan I.,Handayani E.P. 2013. Keanekaragaman Mesofauna dan Makrofauna tanah pada Areal Bekas Tambang Timah di Kabupaten Belitug, Provinsi Kepualauan bangka Belitung. Jurnal Silvikultur Tropika. Vol 4 (1): 35-41

Fitrahtunnisa.,Ilhamdi M.L. 2013. Perbandingan Keanekaragaman dan Predominasi Fauna Tanah dalam Proses Pengomposan Sampah Organik. Jurnal Bumi Lestari. Vol 13 (2):413-421 